\title{
Optimizing production efficiencies of hot water units using building energy simulations - Trade-off between Legionella pneumophila contamination risk and energy efficiency
}

\author{
Elisa Van Kenhove ${ }^{1, *}$, Lien De Backer ${ }^{2}$, and Jelle Laverge ${ }^{1}$ \\ ${ }^{1}$ Research group of Building Physics, Ghent University, Ghent, Belgium
}

\begin{abstract}
The energy needed for domestic hot water represents an important share in the total energy use of well-insulated and airtight buildings. One of the main reasons for this high energy demand is that hot water is produced at temperatures above $60^{\circ} \mathrm{C}$ to mitigate the risk of contaminating the hot water system with Legionella pneumophila. However, this elevated temperature is not necessary for most domestic hot water applications, and has a negative effect on the efficiency of hot water production units. A simulation model has been developed which proposes an alternative to this constant $60^{\circ} \mathrm{C}$ by predicting the Legionella pneumophila concentration dynamically throughout the hot water system. Based on this knowledge, a hot water controller is added to the simulation model that sets a lower hot water comfort temperature in combination with heat shocks. In this paper, the simulation model is used to estimate the energy saving potential in a case study building, at the level of the heat production system by reaching higher production efficiencies. Three different production units, namely an electric boiler, heat pump and solar collector have been investigated. The controller is expected to become an alternative for the current, energy intensive, high temperature tap water heating systems.
\end{abstract}

\section{Introduction}

\subsection{Motivation}

The energy needed for production, storage and distribution of Domestic Hot Water (DHW) represents an important share in the total energy use of well-insulated and airtight buildings. One of the main reasons for this high energy demand is that hot water is produced, stored and distributed at temperatures above $60^{\circ} \mathrm{C}$ to mitigate the risk of contaminating the hot water system with Legionella pneumophila, a bacteria that can cause an acute respiratory disease or severe pneumonia which can be fatal. At $60^{\circ} \mathrm{C}$, Legionella pneumophila growth is stopped and the remaining bacteria are killed. However, this elevated temperature is not necessary for most DHW applications, taking a shower and washing our hands requires a temperature of only $30-40^{\circ} \mathrm{C}$. The disparity between $60^{\circ} \mathrm{C}$ and $40^{\circ} \mathrm{C}$ doubles the temperature difference between hot water system and environment (around $20^{\circ} \mathrm{C}$ ) which has a negative effect on the storage and distribution losses and on the efficiency of hot water production units (such as heat pumps).

\subsection{Novelty}

A simulation model has been developed that proposes an alternative to this constant $60^{\circ} \mathrm{C}$ by predicting the Legionella pneumophila concentration dynamically throughout the hot water system as this concentration cannot be measured in real time [1]. Based on this knowledge, a hot water controller is added to the simulation model that sets a lower hot water comfort temperature in combination with heat shocks when a predefined concentration limit has been reached in simulation. Simulation results of such a controller show savings of more than $35 \%$ on the hot water distribution energy use in an apartment building, without increasing contamination risk [2].

\subsection{Problem statement}

In this paper, the simulation model is used to estimate the additional energy saving potential in a theoretical case study building, at the level of the heat production system by reaching higher production efficiencies if for example a heat pump is used at a lower temperature. Additionally, the additional production energy savings by implementing the controller in three different production units, namely an electric boiler, a heat pump boiler and a heat pump boiler with solar collectors, will be investigated. This new DHW controller is expected to become an important alternative for the current, energy intensive, constant high temperature tap water heating systems.

\subsection{Background}

The $60^{\circ} \mathrm{C}$ temperature limit has been established by investigating the growth dynamics of Legionella pneumophila in laboratory conditions and studying infection cases [3], [4], [5]. At these temperatures the DHW system is considered to be safe.

\footnotetext{
${ }^{*}$ Corresponding author: Elisa.VanKenhove@UGent.be
} 
Similarly, the Domestic Cold Water (DCW) temperature should be kept below $20^{\circ} \mathrm{C}$ to be considered Legionella safe.

At temperatures below $20^{\circ} \mathrm{C}$, the bacteria become dormant but remain viable for months. The bacteria grow best at temperatures between $20^{\circ} \mathrm{C}$ and $45^{\circ} \mathrm{C}$ with an optimum around $35^{\circ} \mathrm{C}-41^{\circ} \mathrm{C}$. Beyond $45^{\circ} \mathrm{C}$, pasteurization starts and higher temperatures will eventually kill the organisms [6]. This can be seen on Figure $1 A$.
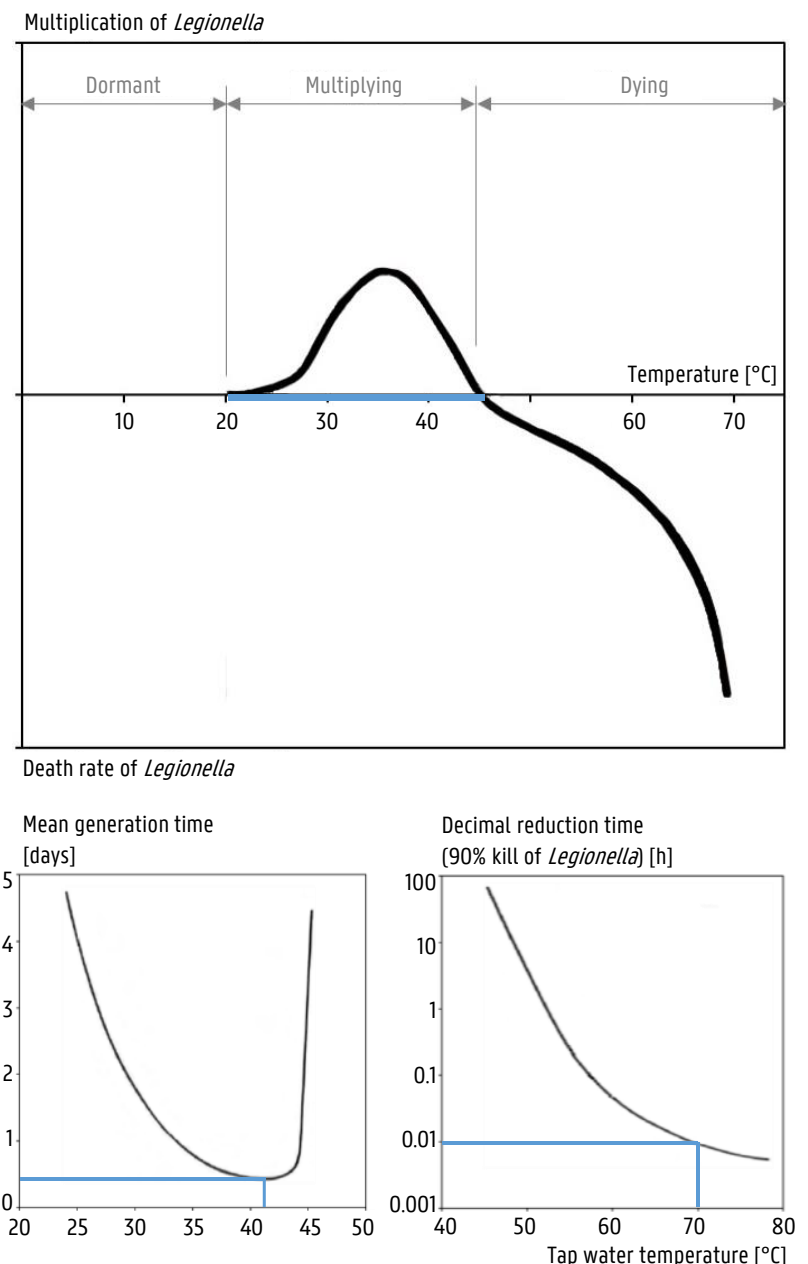

Fig. 1. A. Growth function of Legionella pneumophila in water (adapted from [6]). B. An estimation of mean generation time (time to double the number of cells) of Legionella pneumophila in tap water (data from [7], adapted from [6]). C. The change in decimal reduction time $(90 \%$ reduction of Legionella pneumophila) with temperature (data from [3], [8], adapted from [6]).

On the x-axes, the water temperature in degrees Celsius can be seen and the units on the y-axes are quantified in Figure $I B$ and $I C$ as they both have a different scale. On the y-axes in Figure $1 B$, the time to double the number of Legionella pneumophila (mean generation time) is given and, in Figure $1 C$, the time to reach $90 \%$ reduction in cells (decimal reduction time). Figure $1 B$ is based on data from Yee and Wadowsky [7] from experiments on unsterilized tap water and Figure $1 \mathrm{C}$ is based on data from laboratory experiments [3], [4], [5], [8], and is consistent with field data [9]. Figure $1 B$ shows that the time to double the number of Legionella pneumophila cells in water is less than half a day at $41^{\circ} \mathrm{C}$ and in Figure $1 C$ it can be noted that at $70^{\circ} \mathrm{C}, 90 \%$ of Legionella pneumophila in water gets killed in less than a minute.

\section{Methodology}

Three simulation models of a theoretical case study DHW system have been developed. With these models a dynamic calculation has been performed of the different DHW heat production units, in order to compare the energy savings that correspond with fixing the DHW temperature at $60^{\circ} \mathrm{C}$ (DHW standard regime) and controlling the temperature in the system with a time based heat shock regime.

The Modelica language and Dymola (Dynamic Modelling Laboratory) environment is used to develop the simulation models. The Modelica language is suitable for modelling various kinds of physical systems. It can handle large, complex multi-engineering models and is open to add user defined model components, such as the biological components that are required here. To model the hydraulic system, the Modelica library 3.2.2, the Buildings 5.0.1 library [10] and IDEAS library 2.0.0 [11] has been used. To calculate the Legionella pneumophila concentration, a biologic library developed by the authors has been used that makes it possible to predict the Legionella pneumophila growth. More details regarding the numerical model used can be found in [2].

\section{Case study DHW system}

The principle of the simulation model of the DHW system is shown in Figure 2. The model consists of a component for the production unit, components for the distribution pipes, two distal pipes connected to two tap profiles corresponding with typical DHW kitchen and shower profiles of a single family household and the control of the DHW system. For all three production units, a different simulation model is made. In the next paragraphs, the different case study DHW system components are being discussed. 


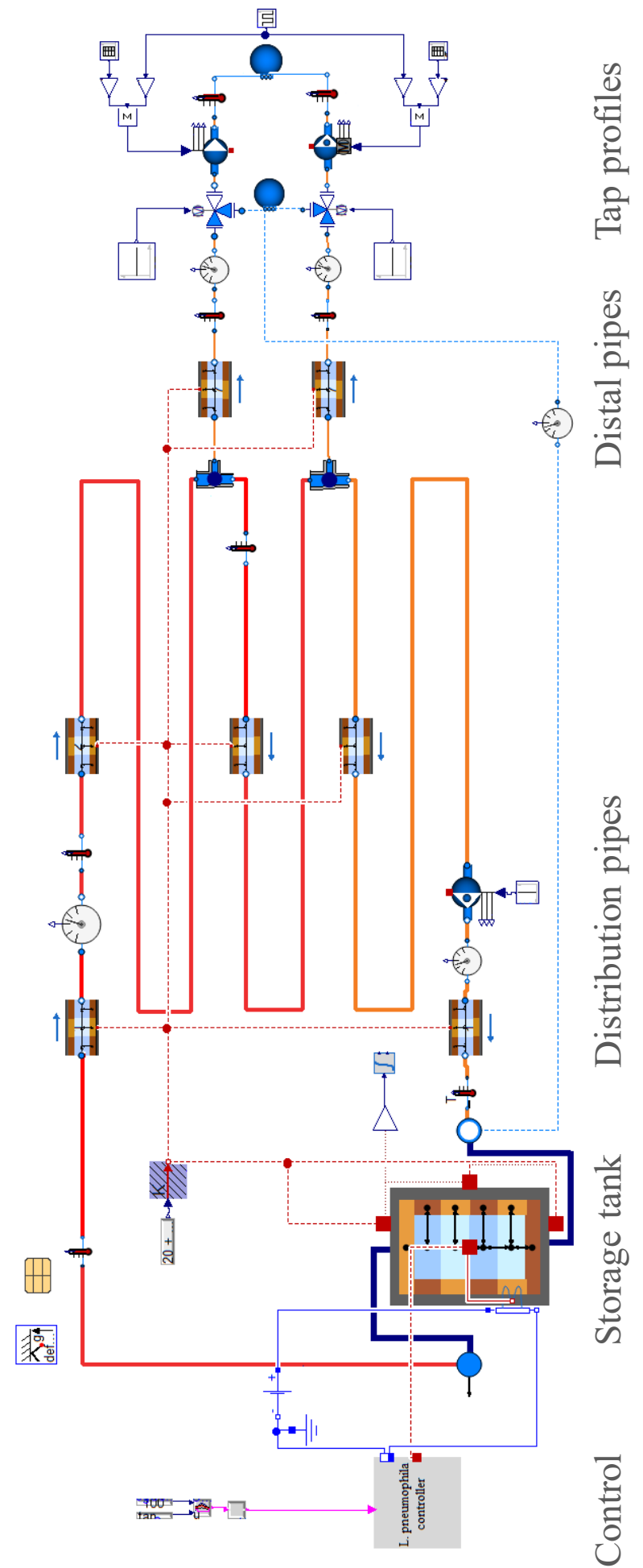

Fig. 2. Simulation model of the DHW system.

\subsection{Production units}

Each production unit consists of a storage tank with a volume of $200 \mathrm{~L}$. The internal height of the tank is $1.5 \mathrm{~m}$ and the internal width is $0.4 \mathrm{~m}$. The tank is insulated with $10 \mathrm{~cm}$ of mineral wool with a thermal conductivity value of $0.04 \mathrm{~W} /(\mathrm{m} \cdot \mathrm{K})$. The water outlet is situated at the top. The water inlet (of return and cold water) is situated at the bottom of the tank.
The thermostat to control the water temperature is located at the bottom layer of the storage tank. To model the temperature in the storage tank, a one dimensional storage tank model is used that divides the height of the tank into several volumes (multi node approach), allowing to calculate the occurring temperature stratification. This is necessary because the growth of Legionella pneumophila bacteria is temperature dependent. By neglecting the stratification in the boiler, the death rate of the bacteria would be too high, leading to an underestimation of the corresponding health risks.

As mentioned before, three different DHW production units are compared. The base component used to model the storage tank will be the same. However, depending on the type of production unit, an additional heat exchanger and/or resistor has been added to the storage tank model.

The component model used to simulate the storage tank is extended from the StratifiedEnhanced tank model, available in the Buildings 5.0.1 library. This component, as it is used in this paper, is updated by the authors in three ways [1].

- Addition of the possibility to vary the height of each volume segment.

- Addition of the possibility to choose different insulation thicknesses for the top, side and bottom of the tank.

- Addition of Legionella pneumophila growth equations to the thermohydraulic model.

The storage tank component used in the case study DHW system simulation model consists of eight layers. The six middle layers have a height of $0.1725 \mathrm{~m}$. The top (layer 1) and bottom layer (layer 8 ) have a height of $0.086 \mathrm{~m}$.

\subsubsection{Electric boiler}

The first production unit is an electric boiler (Figure 2). This holds that heat is added to the tank using an electric immersion heater. The electric immersion heater is placed in horizontal position at the bottom of the tank (layer 7). Generic specifications of the electric boiler are given in Table 1. The efficiency of the boiler is provided in the technical sheet and is determined according to Regulation (EU) No 814/2013 [12].

Table 1. Electric boiler specifications.

\begin{tabular}{|l|c|}
\hline Boiler volume [1] & 200 \\
\hline $\begin{array}{l}\text { Heating power immersion } \\
\text { heater [kW] }\end{array}$ & 3.35 \\
\hline $\begin{array}{l}\text { Efficiency electric boiler } \\
{[\%]}\end{array}$ & 39 \\
\hline $\begin{array}{l}\text { Location of the } \\
\text { immersion heater }\end{array}$ & Layer 7 \\
\hline
\end{tabular}




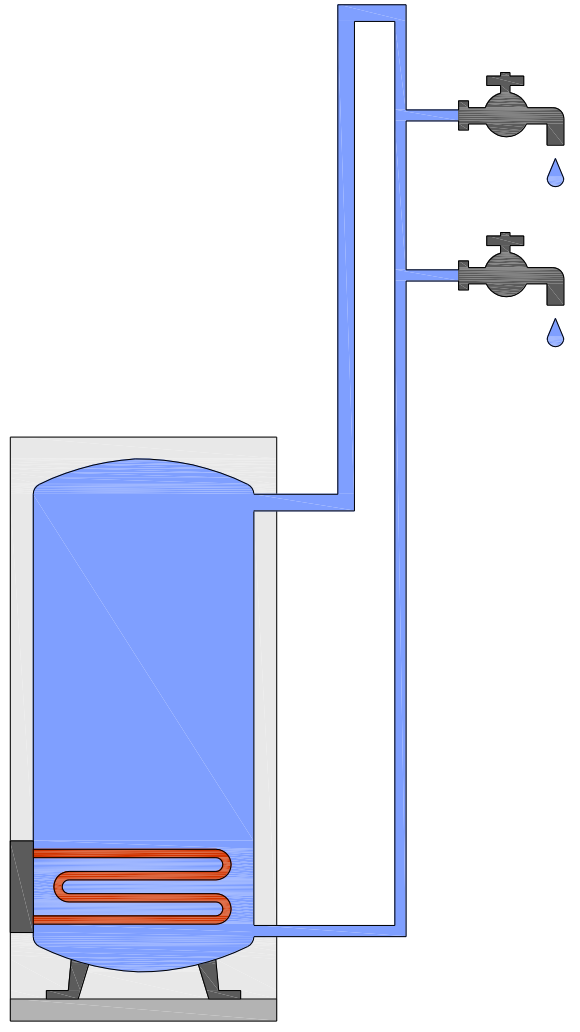

Fig. 2. Schematic view of the case study DHW system with electric boiler as heat production system.

\subsubsection{Heat pump boiler}

The second type of production unit is a heat pump boiler (Figure 3).

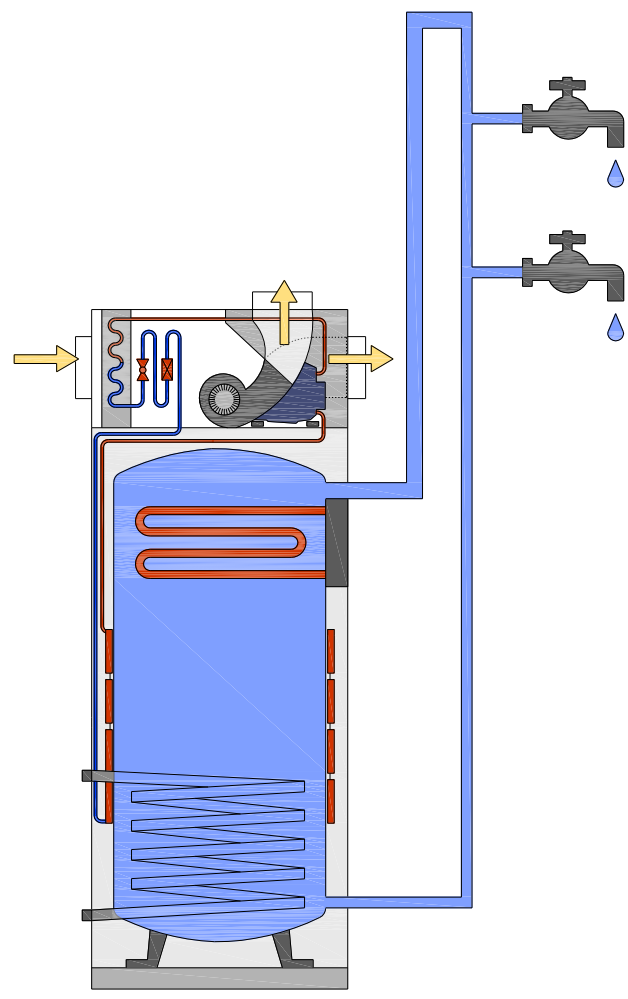

Fig. 3. Schematic view of the case study DHW system with heat pump boiler as heat production system.
This is a combination of the storage tank with a modulating air-to-water heat pump. The second heat exchanger, situated at the bottom of the tank, is not connected in this case.

The heat pump heats the water in the storage tank with a mantle heat exchanger located around the shell of the storage tank. At the top of the tank an additional immersion heater is located. This additional heater is only used in case the heat pump does not achieve the required set point temperature. Generic specifications of the heat pump boiler are given in Table 2. To model the heat pump, the component HeatPumps.Carnot_TCon, available in the Buildings 5.0.1 library is used. This is a model of a heat pump whose Coefficient Of Performance (COP) changes with temperature in the same way as the Carnot efficiency changes.

Table 2. Heat pump boiler specifications.

\begin{tabular}{|l|c|}
\hline Boiler volume [1] & 200 \\
\hline $\begin{array}{l}\text { Heating power heat pump } \\
{[\mathrm{kW}]}\end{array}$ & 2 \\
\hline $\begin{array}{l}\text { Efficiency heat pump } \\
\text { boiler [COP] }\end{array}$ & 3.5 \\
\hline Mass flow rate water $[1 / \mathrm{h}]$ & 50 \\
\hline Mass flow rate air $\left[\mathrm{m}^{3} / \mathrm{h}\right]$ & 450 \\
\hline $\begin{array}{l}\text { Location of the heat } \\
\text { exchanger }\end{array}$ & Layer 3-6 \\
\hline $\begin{array}{l}\text { Heating power additional } \\
\text { immersion heater }[\mathrm{kW}]\end{array}$ & 39 \\
\hline $\begin{array}{l}\text { Efficiency electric boiler } \\
{[\%]}\end{array}$ & Layer 2 \\
\hline $\begin{array}{l}\text { Location of the } \\
\text { immersion heater }\end{array}$ & \\
\hline
\end{tabular}

\subsubsection{Heat pump boiler with solar collectors}

The third production system is comparable with the second production system (heat pump boiler), but additional heat is provided by a solar collector loop (Figure 4). In this case, a second heat exchanger, an immersed coil exchanger, is used that is situated at the bottom of the tank. Generic specifications of the heat pump boiler are given in Table 3 . 


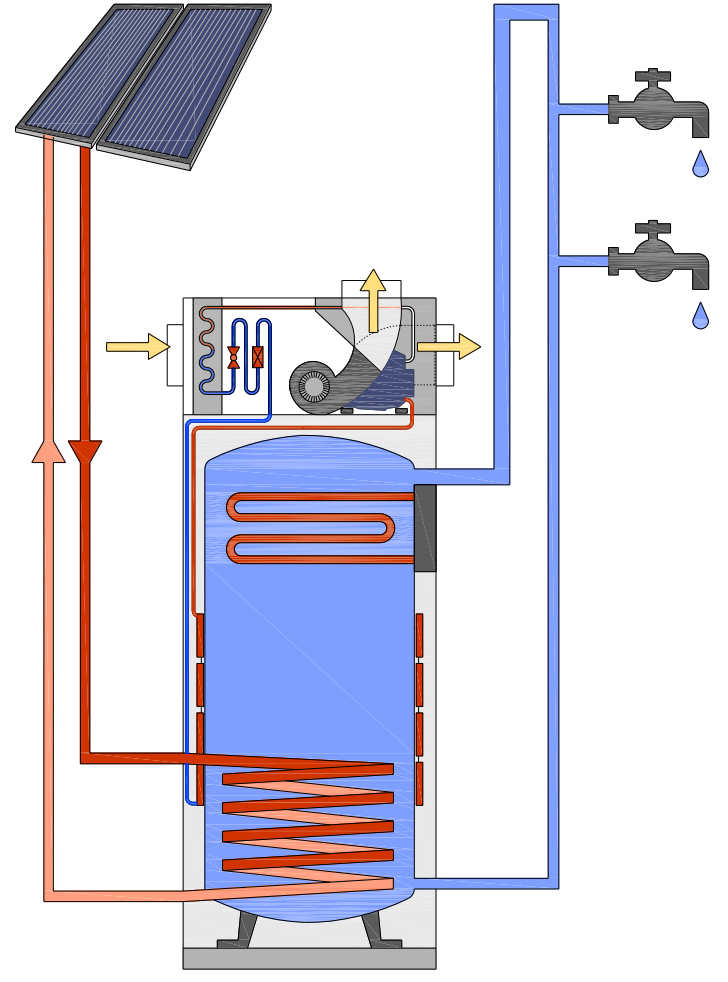

Fig. 4. Schematic view of the case study DHW system with heat pump boiler with solar collectors as heat production system.

The solar collector has a surface area of $3 \mathrm{~m}^{2}$, this is the average area needed for one household (4 people) in a multi-dwelling building [13]. To model the solar collector, the component for a flat plate solar thermal collector 'ASHRAE 93', available in the Buildings 5.0.1 library is used. The Meteonorm climate file of Uccle, Belgium is used to obtain the solar irradiation. The assumption is made that tater, that is incompressible and has a high internal capacity, is used in the solar collector loop.

Table 3. Heat pump boiler with solar collectors specifications.

\begin{tabular}{|l|c|}
\hline Boiler volume [1] & 200 \\
\hline $\begin{array}{l}\text { Heating power heat pump } \\
{[\mathrm{kW}]}\end{array}$ & 2 \\
\hline $\begin{array}{l}\text { Efficiency heat pump } \\
\text { boiler [COP] }\end{array}$ & 3.5 \\
\hline Mass flow rate water $[1 / \mathrm{h}]$ & 50 \\
\hline Mass flow rate air $\left[\mathrm{m}^{3} / \mathrm{h}\right]$ & 450 \\
\hline $\begin{array}{l}\text { Location of the heat } \\
\text { exchanger }\end{array}$ & Layer 3-6 \\
\hline $\begin{array}{l}\text { Heating power additional } \\
\text { immersion heater }[\mathrm{kW}]\end{array}$ & Layer 2-3 \\
\hline $\begin{array}{l}\text { Location of the } \\
\text { immersion heater }\end{array}$ & $45^{\circ} \mathrm{C}$ \\
\hline Solar collector surface tilt & FP - Therma-Lite, HS-20 \\
\hline Type of solar collector & \\
\hline
\end{tabular}

\subsection{Distribution pipes}

The recirculation loop, connected to the test tank, is $24 \mathrm{~m}$ long and consists of insulated multilayer pipes (Alpex). Table 4 shows the characteristics of the recirculation loop and the distal pipes. The characteristics of the pipes are retrieved from the technical ATG data sheet from the manufacturer [14].The mass flow rate of the recirculation loop is calculated in such a way that a maximum temperature difference of $5^{\circ} \mathrm{C}$ between the supply and return temperature is achieved. This depends on the heat losses of the distribution system. With the $65-60^{\circ} \mathrm{C}$ temperature regime and a constant environmental temperature of $15^{\circ} \mathrm{C}$ (in shafts), this results in a mass flow rate of $0.14 \mathrm{~kg} / \mathrm{s}$. Accordingly with a regime of $50-45^{\circ} \mathrm{C}$, this is $0.08 \mathrm{~kg} / \mathrm{s}$.

Table 4. Length and diameters of the distribution pipes.

\begin{tabular}{|l|c|}
\hline Supply recirculation pipe & \\
\hline Length [m] & 14 \\
\hline Outer diameter [m] & 0.026 \\
\hline Thickness pipe [m] & 0.003 \\
\hline Insulation [m] & 0.015 \\
\hline Heat loss coefficient [W/m·K] & 0.23 \\
\hline Return recirculation pipe & \\
\hline Length [m] & 10 \\
\hline Outer diameter [m] & 0.016 \\
\hline Thickness pipe [m] & 0.002 \\
\hline Insulation [m] & 0.015 \\
\hline Heat loss coefficient [W/m·K] & 0.17 \\
\hline Correction factor for thermal bridges [\%] & 20 \\
\hline Distal pipes & \\
\hline Length of one distal pipe [m] & 5.5 \\
\hline Insulation [m] & 0 \\
\hline
\end{tabular}

To model the distribution system the Pipe component from the Buildings 5.0.1 library is adapted with biological growth equations. The pipe model used is based on the finite volume method. Every pipe component is subdivided in one node every metre pipe length. Perfect mixing of water is assumed in every node. Flow reversal (back flow) is taken into account in the pipe model, based on pressure differences. Advection is included in two directions.

\subsection{Taps}

The required comfort temperature at the tap is $45^{\circ} \mathrm{C}$. This temperature can be reached with a mixing valve (threeway-valve) in case the production unit produces water at or above $60^{\circ} \mathrm{C}$ or by direct withdrawal if water with a temperature around $45^{\circ} \mathrm{C}$ is produced.

Table 5 shows the daily tap profile schedule used in the simulation model. The total tapped daily water volume is 211.401. The volume flow rate at the taps (at $60^{\circ} \mathrm{C}$ ) is calculated based on DIN 1988-300 [15]. 
Table 5. Daily tap profile schedule.

\begin{tabular}{|c|l|c|c|c|}
\hline $\begin{array}{l}\text { Start } \\
\text { time } \\
\text { [hour] }\end{array}$ & $\begin{array}{l}\text { Draw-off } \\
\text { type } \\
{[-]}\end{array}$ & $\begin{array}{l}\text { Flow } \\
\text { rate } \\
{[\mathbf{L} / \mathbf{m i n}]}\end{array}$ & $\begin{array}{l}\text { Tap } \\
\text { duration } \\
{[\mathbf{s}]}\end{array}$ & $\begin{array}{l}\text { Tapped } \\
\text { volume } \\
{[\mathbf{L}]}\end{array}$ \\
\hline $6: 59$ & $\begin{array}{l}\text { Purge of the } \\
\text { shower/kitchen } \\
\text { pipe }\end{array}$ & 9.00 & 10 & 1.50 \\
\hline $7: 00$ & Shower & 9.00 & 355 & 53.25 \\
\hline $7: 10$ & Shower & 9.00 & 393 & 58.95 \\
\hline $8: 00$ & Shower & 9.00 & 296 & 44.40 \\
\hline $12: 00$ & Kitchen faucet & 4.20 & 6 & 0.42 \\
\hline $12: 30$ & Kitchen faucet & 4.20 & 20 & 1.40 \\
\hline $13: 45$ & Kitchen faucet & 4.20 & 30 & 2.10 \\
\hline $18: 15$ & Children's bath & 9.00 & 311 & 46.65 \\
\hline $19: 00$ & Kitchen faucet & 4.20 & 6 & 0.42 \\
\hline $19: 15$ & Kitchen faucet & 4.20 & 3 & 0.21 \\
\hline $20: 00$ & Kitchen faucet & 4.20 & 30 & 2.10 \\
\hline
\end{tabular}

\subsection{Control}

The first modelling part was modelling the different system components, another part consists of modelling the controls.

In case the electric boiler is used, a simple on/off controller is used to control the power of the immersion heater. The dead band of the thermostat is set at $2{ }^{\circ} \mathrm{C}$.

In case the storage tank is indirectly heated through one or two heat exchangers (connected to the heat pump and solar collectors), a pump model is used to control the fluid flows between both components. The on/off signal for the pumps and the set point temperature of their controllers are received from control blocks available in the Buildings 5.0.1 library.

Two control scenarios are studied. In the first scenario the tank is operating at $62-60^{\circ} \mathrm{C}$. In the second scenario, the temperature in the tank is kept at $48^{\circ} \mathrm{C}$, assuring a temperature of $45^{\circ} \mathrm{C}$ at the taps (reverse calculation based on the distribution losses). Once a week, a heat shock takes place maintaining the temperature at $65^{\circ} \mathrm{C}$ during two hours. At the end of the heat shock, water usage takes place during one minute in order to also flush the distal pipes (Purge of the shower/kitchen pipe in Table 5).

\section{Results}

To compare the different simulation results based on energy use and occurring Legionella pneumophila concentration, the following simulation setup is chosen.

- Start time: 0s

- $\quad$ Stop time: 1209 600s (14 days)

- Integration algorithm: Euler (explicit)

- Integration tolerance: 0.0001

- $\quad$ Time step: $1 \mathrm{~s}$

The outputs that are investigated are:
- Water temperatures throughout the DHW system.

- Legionella pneumophila concentrations at the two points of use.

- Energy use of the different production units.

- Production and distribution heat losses.

The predicted temperature and the Legionella pneumophila concentration at the points of use is shown in Figure 5. In case the temperature in the tank is constantly kept at a minimum of $60^{\circ} \mathrm{C}$ (according to the current standards), it can be seen that the concentration of Legionella pneumophila is almost zero during the whole simulation period. As expected Legionella pneumophila is always in starvation mode due to this elevated temperature. The steps in the concentration are caused by the tap profiles. While tapping water from the recirculation loop, in which almost no Legionella pneumophila is present due to the constant temperature of $60^{\circ} \mathrm{C}$, enters the distal pipe. After the tap, the temperature of the water in the distal pipe decreases, bringing the temperature shortly in a zone (between $20^{\circ} \mathrm{C}$ and $45^{\circ} \mathrm{C}$ ) where Legionella pneumophila growth is possible (Figure 1A).

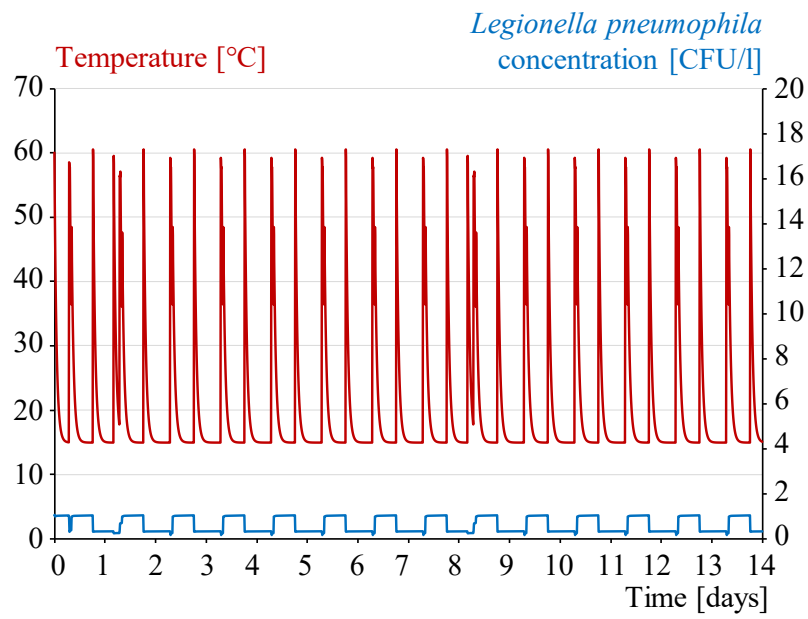

Fig. 5. Temperature and Legionella pneumophila concentrations at the points of use.

In case the set point temperature is kept at $48^{\circ} \mathrm{C}\left(45^{\circ} \mathrm{C}\right.$ is reached at the tap), the simulation results show that between two heat shocks, the Legionella pneumophila bacteria cannot grow significantly (Figure 6). The dangerous contamination level of $1000 \mathrm{CFU} / 1$ (Colony Forming Units a litre) is never reached. There are three reasons to explain observation.

- The Legionella pneumophila bacteria die during the heat shock.

- The temperature coming from the storage tank is $48^{\circ} \mathrm{C}$, this temperature is high enough to eliminate Legionella pneumophila.

- The temperature in the distal pipes cools down quickly to $15^{\circ} \mathrm{C}$ in between two taps, below $20^{\circ} \mathrm{C}$ Legionella pneumophila is dormant. 


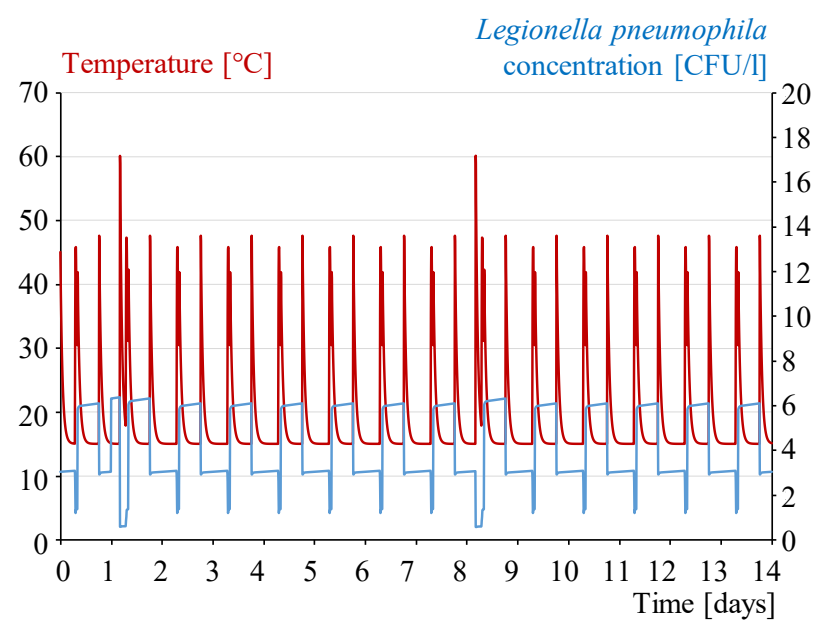

Fig. 6. Temperature and Legionella pneumophila concentrations at the points of use.

The energy use of the different types of production units is shown in Table 6. This energy use of each production unit takes into account the efficiency of the system. In case the production unit consists of a heat pump, the time dependent COP is used, which is retrieved from the simulation study. In case the temperature regime is constant $60^{\circ} \mathrm{C}$, the average COP of the air-to-water heat pump is 2.32. In case of the heat shock regime, water in the storage tank is stored at $48^{\circ} \mathrm{C}\left(45^{\circ} \mathrm{C}\right.$ is reached at the taps), the average COP is 3.45 . For the electric immersion heater, the efficiency is temperature independent and thus continuously $39 \%$. In the case of the heat pump boiler with solar collectors, 960 sun hours a year are assumed. The average amount of sun hours in Belgium for example is between 1400 and 1700 a year [16].

Table 6. Energy use of different production unit scenarios [kWh/year].

\begin{tabular}{|l|c|c|}
\hline $\begin{array}{l}\text { Production } \\
\text { unit }\end{array}$ & $\begin{array}{l}\text { Energy use at } \\
\text { constant } \mathbf{6 0}^{\circ} \mathbf{C} \\
\text { [kWh/year] }\end{array}$ & $\begin{array}{l}\text { Energy use with set } \\
\text { point temperature of } \\
\mathbf{4 5}^{\circ} \mathbf{C} \text { and heat shock } \\
\text { once a week (2 hours at } \\
\mathbf{6 5}^{\circ} \mathbf{C} \text { ) [kWh/year] }\end{array}$ \\
\hline $\begin{array}{l}\text { Electric } \\
\text { boiler }\end{array}$ & 13415 & 11524 \\
\hline $\begin{array}{l}\text { Heat pump } \\
\text { boiler }\end{array}$ & 3731 & 2147 \\
\hline $\begin{array}{l}\text { Heat pump } \\
\text { boiler with } \\
\text { solar } \\
\text { collectors }\end{array}$ & 1997 & 776 \\
\hline
\end{tabular}

\subsection{Comparison of control regimes}

In case the heat shock regime is used, the total energy use of all production units decreases. For the electric boiler it decreases with $14 \%$, for the heat pump boiler with $42 \%$ and with $62 \%$ for the heat pump boiler combined with solar collectors. As can be seen in Figure 5 the contamination risk does not increase.
On the one hand, lower energy uses at $45^{\circ} \mathrm{C}$ could be related to the lower distribution losses to the environment. For all production units, the distribution losses are similar. On the other hand, lower storage heat losses occur. Although a higher volume flow rate at the taps occurs at $45^{\circ} \mathrm{C}$ as almost no mixing occurs with cold water and thus leading to a higher volume of cold water that has to be reheated by the production unit, this increase in volume will be compensated by the fact that it has to be heated until $45^{\circ} \mathrm{C}$ instead of $60^{\circ} \mathrm{C}$.

For the heat pump, a third reason is related to the efficiency of the production unit which is higher at the $45^{\circ} \mathrm{C}$ heat shock regime than at the $60^{\circ} \mathrm{C}$ standard regime. As a consequence, less electricity is necessary to produce the same amount of energy.

\subsection{Comparison of production units}

Compared to the electric boiler, heat pump boilers have a lower energy use. This is related to the additional energy savings the use of a Carnot cycle technology offers.

When a heat pump boiler with solar collector is used, "free" energy is produced during the day (except for the additional electricity use of the circulation pump). This results in an additional energy saving compared to the heat pump boiler without a solar collector.

\section{Conclusions}

A simulation model has been developed which proposes an alternative to this constant $60^{\circ} \mathrm{C}$ by predicting the Legionella pneumophila concentration dynamically throughout the hot water system. A hot water controller is added to the simulation model that sets a lower hot water set point temperature in combination with heat shocks when a predefined concentration limit has been reached. Simulation results of such a controller, compared to the standard $60^{\circ} \mathrm{C}$ regime, show savings on DHW production energy use in a case study DHW system on household scale of respectively $14 \%$ for an electric boiler, $42 \%$ for a heat pump boiler and $62 \%$ for a heat pump boiler with solar collector, without increasing contamination risk.

\section{Future research}

Making the simulation models is a first step to evaluate the controller. In future research, a representation of the simulation model will be built as a test rig in laboratory.

The new domestic hot water controller is expected to become an important alternative for the current, energy intensive, constant high temperature tap water heating systems. 


\section{References}

1. E. Van Kenhove, L. De Backer, A. Janssens, J. Laverge. Simulation of Legionella Concentration in Domestic Hot Water: Comparison of Pipe and Boiler Models, Journal of Building Performance Simulation (2018)

2. E. Van Kenhove. Coupled thermohydraulic and biologic modelling of Legionella pneumophila proliferation in domestic hot water systems. $\mathrm{PhD}$ dissertation (2018)

3. J.E. Stout, M.G. Best, V.L. Yu. Susceptibility of members of the family Legionellaceae to thermal stress: implication for heat eradication methods in water distribution systems, Ashrae Journal 46(5):52-54 (1986) 4. R. Schulze-Röbbecke, M. Rodder, M. Exner. Multiplication and inactivation temperatures of naturally occurring legionellae, Zentralblatt für Bakteriologie, Mikrobiologie und Hygiene B184:494-500 (1987)

5. G.N. Sanden, B.S. Fields, J.M. Barbaree, J.C. Feeley. Viability of Legionella pneumophila in chlorine free water at elevated temperatures, Current Microbiology 18:61-65 (1989)

6. G.W. Brundrett. Legionella and Building Services. Oxford (1992)

7. R.B. Yee, R.M. Wadowsky. Multiplication of Legionella pneumophila in unsterilized tap water, Journal of Applied Environmental Microbiology, 43:1330-1334 (1982)
8. P.J. Dennis, D. Green, B.P.C. Jones. A note on the temperature tolerance of Legionella, Journal of Applied Bacteriology, 56(2):349-350 (1984)

9. D.G. Groothuis, H.R. Veenendaal, H.L. Dijkstra. Influence of temperature on the number of Legionella pneumophila in hot water systems, Journal of Applied Bacteriology, 59:529-536 (1985)

10. M. Wetter, W. Zuo, T.S. Nouidui, X. Pang. Modelica buildings library, Journal of Building Performance Simulation 7(4):253-270 (2014)

11. F. Jorissen, G. Reynders, R. Baetens, D. Picard, D. Saelens, L. Helsen. Implementation and verification of the IDEAS building energy simulation library, Journal of Building Performance Simulation, 1-20 (2018)

12. Commission Regulation (EU) No $814 / 2013$ of 2 August 2013 implementing Directive 2009/125/EC of the European Parliament and of the Council with regard to ecodesign requirements for water heaters and hot water storage tanks. Text with EEA relevance OJ L 239, 6.9.2013, 162-183 (2013)

13. D. Zijdemans. Vannbaserte oppvarmings- og kjølesystemer, Oslo, SkarlandPress (2012)

14. ATG data sheet, http://www.butgb.be/content/technical_approval/downlo ad.cfm/ATG2461_150921_N.pdf, updated on 21/09/2015, accessed on $1 \overline{5} / 01 / 2019$ (2015)

15. DIN 1988-300 (2012)

16. KMI.

Klimaatatlas, https://www.meteo.be/meteo/view/nl/16788784-

Klimaatatlas.html, updated in 2019, accessed on 15/01/2019 (2019) 